NASA/TM-2002-211833

IECEC-2002-20154

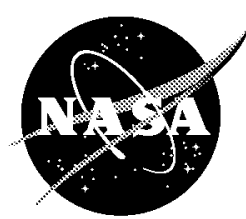

\title{
Thin-Film Organic-Based Solar Cells for Space Power
}

Sheila G. Bailey

Glenn Research Center, Cleveland, Ohio

Jerry D. Harris

Cleveland State University, Cleveland, Ohio

Aloysius F. Hepp

Glenn Research Center, Cleveland, Ohio

Emily J. Anglin

Ohio Aerospace Institute, Brook Park, Ohio

Ryne P. Raffaelle

Rochester Institute of Technology, Rochester, New York

Harry R. Clark, Jr.

Townsend Science and Engineering, Inc., Fitchourg, Massachusetts

Susan T.P. Gardner

Physical Sciences, Inc., Andover, Massachusetts

Sam S. Sun

Norfolk State University, Norfolk, Virginia 
The NASA STI Program Office ... in Profile

Since its founding, NASA has been dedicated to the advancement of aeronautics and space science. The NASA Scientific and Technical Information (STI) Program Office plays a key part in helping NASA maintain this important role.

The NASA STI Program Office is operated by Langley Research Center, the Lead Center for NASA's scientific and technical information. The NASA STI Program Office provides access to the NASA STI Database, the largest collection of aeronautical and space science STI in the world. The Program Office is also NASA's institutional mechanism for disseminating the results of its research and development activities. These results are published by NASA in the NASA STI Report Series, which includes the following report types:

- TECHNICAL PUBLICATION. Reports of completed research or a major significant phase of research that present the results of NASA programs and include extensive data or theoretical analysis. Includes compilations of significant scientific and technical data and information deemed to be of continuing reference value. NASA's counterpart of peerreviewed formal professional papers but has less stringent limitations on manuscript length and extent of graphic presentations.

- TECHNICAL MEMORANDUM. Scientific and technical findings that are preliminary or of specialized interest, e.g., quick release reports, working papers, and bibliographies that contain minimal annotation. Does not contain extensive analysis.

- CONTRACTOR REPORT. Scientific and technical findings by NASA-sponsored contractors and grantees.
- CONFERENCE PUBLICATION. Collected papers from scientific and technical conferences, symposia, seminars, or other meetings sponsored or cosponsored by NASA.

- SPECIAL PUBLICATION. Scientific, technical, or historical information from NASA programs, projects, and missions, often concerned with subjects having substantial public interest.

- TECHNICAL TRANSLATION. Englishlanguage translations of foreign scientific and technical material pertinent to NASA's mission.

Specialized services that complement the STI Program Office's diverse offerings include creating custom thesauri, building customized data bases, organizing and publishing research results... even providing videos.

For more information about the NASA STI Program Office, see the following:

- Access the NASA STI Program Home Page at http://wwo.sti.nasa.gov

- E-mail your question via the Internet to help@stinasa.gov

- Fax your question to the NASA Access Help Desk at 301-621-0134

- Telephone the NASA Access Help Desk at 301-621-0390

- Write to: NASA Access Help Desk NASA Center for AeroSpace Information 7121 Standard Drive Hanover, MD 21076 


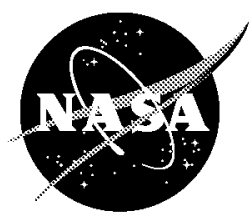

\section{Thin-Film Organic-Based Solar Cells for Space Power}

Sheila G. Bailey

Glenn Research Center, Cleveland, Ohio

Jerry D. Harris

Cleveland State University, Cleveland, Ohio

Aloysius F. Hepp

Glenn Research Center, Cleveland, Ohio

Emily I. Anglin

Ohio Aerospace Institute, Brook Park, Ohio

Ryne P. Raffaelle

Rochester Institute of Technology, Rochester, New York

Harry R. Clark, Jr.

Townsend Science and Engineering, Inc., Fitchburg, Massachusetts

Susan T.P. Gardner

Physical Sciences, Inc., Andover, Massachusetts

Sam S. Sun

Norfolk State University, Norfolk, Virginia

Prepared for the

37th Intersociety Energy Conversion. Engineering Conference sponsored by the Institute of Electrical and Electronics Engineers, Electron Devices Society Washington, DC, July 28-August 2, 2002

National Aeronautics and

Space Administration

Glenn Research Center 
Trade names or manufacturers' names are used in this report for identification only. This usage does not constitute an official endorsement, either expressed or implied, by the National Aeronautics and Space Administration.

Available from

NASA Center for Aerospace Information 7121 Standard Drive

Hanover, MD 21076
National Technical Information Service 5285 Port Royal Road Springfield, VA 22100

Available electronically at http://gltrs.grcnasa.gov 


\title{
THIN-FILM ORGANIC-BASED SOLAR CELLS FOR SPACE POWER
}

\author{
Sheila G. Bailey \\ National Aeronautics and Space Administration \\ Glenn Research Center \\ Cleveland, Ohio 44135 \\ 216-433-2228, 216-433-6106, sheila.g.bailey@grc.nasa.gov \\ Jerry D. Harris \\ Cleveland State University \\ Cleveland, Ohio 44115 \\ Aloysius F. Hepp \\ National Aeronautics and Space Administration \\ Glenn Research Center \\ Cleveland, Ohio 44135 \\ Emily J. Anglin \\ Ohio Aerospace Institute \\ Brook Park, Ohio 44142 \\ Ryne P. Raffaelle \\ Rochester Institute of Technology \\ Rochester, New York 14623 \\ Harry R. Clark, Jr. \\ Townsend Science and Engineering, Inc. \\ Fitchburg, Massachusetts 01420 \\ 978-345-9090, 978-345-9292, sundye@ziplink.net \\ Susan T.P. Gardner \\ Physical Sciences Inc. \\ Andover, Massachusetts 01810 \\ 978-738-8231,978-689-3232, gardner@psicorp.com \\ Sam S. Sun \\ Norfolk State University \\ Norfolk, Virginia 23504 \\ 757-823-2993, 757-823-9054, ssun@nsu.edu
}

\begin{abstract}
Recent advances in dye-sensitized and organic polymer solar cells have lead NASA to investigate the potential of these devices for space power generation. Dye-sensitized solar cells were exposed to simulated low-earth orbit conditions and their performance evaluated. All cells were characterized under simulated air mass zero (AM0) illumination. Complete cells were exposed to pressures less than $1 \times 10^{-7}$ torr for over a month, with no sign of sealant failure or electrolyte leakage. Cells from Solaronix SA were rapid thermal cycled under simulated low-earth orbit conditions. The cells were cycled 100 times from $-80^{\circ} \mathrm{C}$ to $80^{\circ} \mathrm{C}$, which is equivalent to 6 days in orbit. The best cell had a $4.6 \%$ loss in efficiency as a result of the thermal cycling. In a separate project, novel -Bridge-Donor-Bridge-Acceptor- (-BDBA-) type conjugated block copolymer systems have been synthesized and characterized by photoluminescence $(\mathrm{PL})$. In comparison to pristine donor or acceptor, the PL emissions of final -B-D-B-A- block copolymer films were quenched over $99 \%$. Effective and efficient photo induced electron transfer and charge separation occurs due to the interfaces of micro phase separated donor and acceptor blocks. The system is very promising for a variety high efficiency
\end{abstract}

light harvesting applications. Under an SBIR contract, fullerene-doped polymer-based photovoltaic devices were fabricated and characterized. The best devices showed overall power efficiencies of $\sim 0.14 \%$ under white light. Devices fabricated from $2 \%$ solids content solutions in chlorobenzene gave the best results. Presently, device lifetimes are too short to be practical for space applications.

\section{INTRODUCTION}

Inexpensive, lightweight inorganic materials such as amorphous $\mathrm{Si}, \mathrm{CulnSe_{2 }}$ and $\mathrm{CdTe}$ are currently being explored for space-based energy conversion. Next generation thin-film technologies may well involve a revolutionary change in materials to organicbased devices. These materials offer the possibility of even lower-cost and higher power-to-weight ratios that may be mission enabling for Space Solar Power, Solar Electric Propulsion, and off-grid military applications, as well as numerous civilian and commercial off-grid uses. NASA Glenn Research Center currently supports a small in-house and extramural program exploring these technologies. However, to be useful for applications in space, any solar cell which is developed must not only meet weight and AMO efficiency goals, but also must be 
durable enough to survive launch and thermal and radiation environments of space.

Nanocrystalline dye-sensitized solar cells (ncDSC) have been under development for over a decade, and the ruthenium dyes are reported to be stable to at least $180{ }^{\circ} \mathrm{C}$ and under exposure to ultraviolet radiation (Amirnas et al., 2000; Kohle et al., 1997). Reported efficiencies for liquid electrolyte cells fabricated on glass have been in excess of $10 \%$ (AM1.5) (Gratzel, 2000) and recent advances in solid electrolytes (Bach et al., 1998) have lead us to evaluate dye-sensitized solar cells for space power applications. Additionally, under a NASA SBIR program robust long-lived dye solar cells on lightweight plastic have been reduced to practice. At even modest efficiencies this program holds the realistic promise for topping the 1 kilowatt per kilogram power to weight ratio in the very near future.

Both the individual components and complete dyesensitized solar cells have had extensive terrestrial environment testing, and the results of the testing have been very promising (Hinsch et al., 2001). However, very little, if any space environment testing has been done on dye-sensitized cells. Our in-house work focused on testing dye-sensitized solar cells under simulated LEO space conditions. Typically, LEO missions are flown in circular orbits at space shuttle altitudes and can range up to $2000 \mathrm{~km}$. They are characterized by low levels of radiation from trapped electrons and protons, exposure to UV radiation and 6000 thermal cycles per year as the spacecraft moves in and out of the earth's shadow and completes an orbit roughly every 90 minutes. LEO missions put a premium on beginning-of-life (BOL) efficiency and thermal cycle survivability, with typical temperature ranges of 200-350K (Bailey and Flood, 1998). Typical LEO missions applications are weather monitoring, earth observation/global climate monitoring, military observation and telecommunication systems. Life times for these missions range from several months to several years.

In addition to the dye-sensitized solar cell projects, work has also been supported in the area of organic polymer photovoltaics. The high volume, low cost fabrication ability of organic cells will allow for square miles of solar cell production at one-tenth the cost of conventional inorganic materials. Plastic solar cells take a minimum of storage space and can be inflated or unrolled for deployment. In comparison to current commercial inorganic photovoltaic materials, polymeric photovoltaic materials have the advantages of versatile fabrication schemes and low cost on large-scale production, therefore exhibit potential for future large-scale solar industry. For space and any portable applications, the lightweight, flexible shape of polymers are other key advantages. While the power conversion efficiency for inorganic photovoltaic cells have reached nearly $30 \%$ (Green et al., 2001), it is only a fraction of that for recently developed polymer photovoltaic systems (Yu et al., 1995; Granstrom et al., 1998; Shaheen et al., 2001). Therefore, development of highly efficient polymeric photovoltaic materials, and a better understanding of the fundamental mechanisms involved in polymer optoelectronic processes has become a critical research effort. The group at Norfolk State University has been developing new donor-acceptor polymer systems for photovoltaic applications, while the group at Physical Sciences Inc., has prepared working devices using $\mathrm{C}_{60}$-doped polymers. A summary of the work from the different groups will be presented.

\section{RESULTS AND DISCUSSION Dye-sensitized solar cells}

For any solar cell to operate in space, it must be able to tolerate the vacuum of space. This is a particularly important concern for dye-sensitized solar cells, because of the liquid electrolytes commonly used in these devices. Spacecraft in low-earth orbit will typically experience pressures on the order of $10^{-6}$ torr. To demonstrate that nc-DSC can tolerate these types of vacuums, several cells were pumped to a pressure of $<1 \times 10^{-7}$ torr under dynamic vacuum for over a month, and the cells exhibited no signs of leakage or sealant failure.

Two complete cells were also obtained from Solaronix SA (Aubonne, Switzerland) and upon receipt were characterized under AMO illumination (figure 1, table 1). The cells were then stored in a desiccator at room temperature for 52 days while waiting to be rapid thermal cycled and during this time received only limited exposure to ambient light. Prior to thermal cycling, the cells were again characterized under calibrated, simulated AMO illumination (figure 2, table 1). It was observed that one of the cells (cell 1) had a substantial decrease in performance, and the second cell (cell 2) had only a modest loss of performance. The large drop in current for cell 1 is simply attributed to it being a faulty cell. In the literature, these cells have demonstrated long shelf lives.

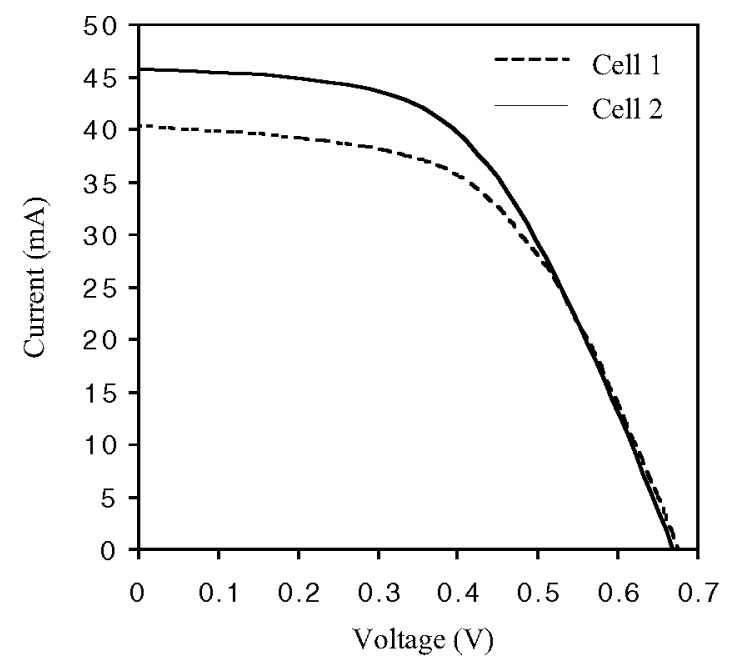

FIGURE. 1. IV CURVES FOR CELLS 1 AND 2 WHEN CELLS WERE INITIALLY RECEIVED. 
TABLE 1. AIR MASS ZERO CHARACTERIZATION DATA FOR DYE-SENSITIZED CELLS.

\begin{tabular}{|r|l|l|l|}
\hline & $\begin{array}{l}\text { Initial AM0 } \\
\text { Measure }\end{array}$ & $\begin{array}{l}\text { Pre-cycling } \\
\text { Measure }\end{array}$ & $\begin{array}{l}\text { Post-cycling } \\
\text { Measure }\end{array}$ \\
\hline Cell 1, area & $3.68 \mathrm{~cm}^{2}$ & $3.68 \mathrm{~cm}^{2}$ & $3.68 \mathrm{~cm}^{2}$ \\
\hline Isc & $40.3 \mathrm{~mA}$ & $14.3 \mathrm{~mA}$ & $10.8 \mathrm{~mA}$ \\
\hline Voc & $677 \mathrm{mV}$ & $687 \mathrm{mV}$ & $663 \mathrm{mV}$ \\
\hline Imax & $32.4 \mathrm{~mA}$ & $11.1 \mathrm{~mA}$ & $8.76 \mathrm{~mA}$ \\
\hline Vmax & $454 \mathrm{mV}$ & $499 \mathrm{mV}$ & $472 \mathrm{mV}$ \\
\hline Pmax & $14.7 \mathrm{~mW}$ & $5.55 \mathrm{~mW}$ & $4.13 \mathrm{~mW}$ \\
\hline F.F. & 53.9 & 56.3 & 57.6 \\
\hline Eff. & $2.92 \%$ & $1.10 \%$ & $0.82 \%$ \\
\hline Isc & $45.8 \mathrm{~mA}$ & $41.4 \mathrm{~mA}$ & $36.5 \mathrm{~mA}$ \\
\hline Voc & $670 \mathrm{mV}$ & $672 \mathrm{mV}$ & $657 \mathrm{mV}$ \\
\hline Imax & $37.7 \mathrm{~mA}$ & $33.4 \mathrm{~mA}$ & $30.0 \mathrm{~mA}$ \\
\hline Vmax & $426 \mathrm{mV}$ & $404 \mathrm{mV}$ & $431 \mathrm{mV}$ \\
\hline Pmax & $16.0 \mathrm{~mW}$ & $13.5 \mathrm{~mW}$ & $12.9 \mathrm{~mW}$ \\
\hline F.F. & 52.3 & 48.5 & 54.0 \\
\hline Eff. & $3.16 \%$ & $2.66 \%$ & $2.54 \%$ \\
\hline & & &
\end{tabular}

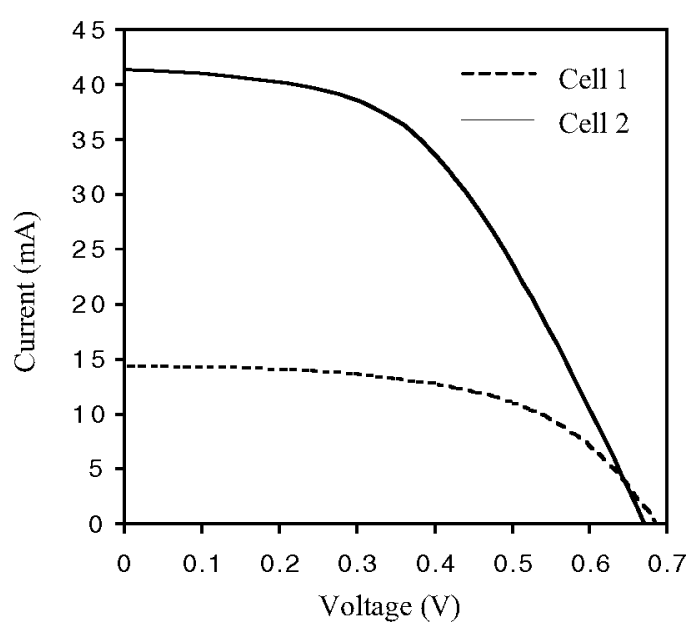

FIGURE. 2. IV CURVES MEASURED FOR CELLS 1 AND 2 FOLLOWING STORAGE AND PRIOR TO RAPID THERMAL CYCLING.

Following the second AMO characterization, the cells were rapid thermal cycled between $-80^{\circ} \mathrm{C}$ and $80^{\circ} \mathrm{C}$, which roughly corresponds to the temperature swings the cells would experience in a low-earth orbit. A spacecraft in low-earth orbit endures approximately 6000 thermal cycles per year. For our initial testing of the cells, they were rapid thermal cycled 100 times, which corresponds to six days in orbit. After thermal cycling, the cells were once again characterized under AMO illumination (figure 3, table 1). There was a measurable decrease in the performance of both cells, with that of cell 1 being the most dramatic. Upon examination, cell 1 lost a substantial amount of electrolyte during thermal cycling. The electrolyte appears to have escaped under or through the Surlyn 1702 polymer seal, as the seal was stained yellow on one side of the cell following thermal cycling. Physically, cell 2 survived the thermal cycling reasonably well, with no signs of electrolyte loss. However, it did have a $4.6 \%$ drop in efficiency, caused mainly from a decrease in current produced by the cell.

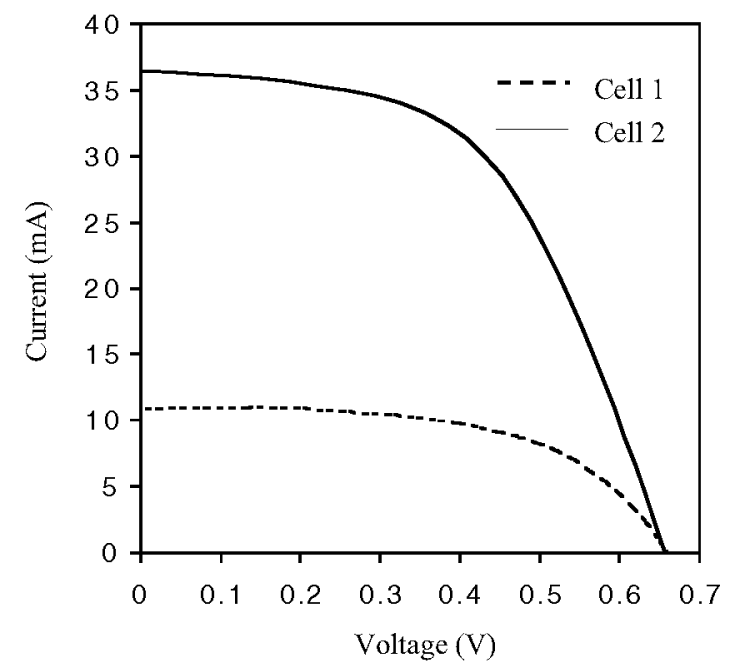

FIGURE. 3. IV CURVES FOR CELLS 1 AND 2 FOLLOWING RAPID THERMAL CYCLING.

Current dye-sensitized solar cells lack stability at elevated temperatures $\left(85^{\circ} \mathrm{C}\right.$ ) (Hinsch et al., 2001). However, due to our limited amount of data, it is difficult to determine whether the decrease in performance of cell 2 was from the elevated cycle temperatures, or another failure mechanism. A longterm study is in progress, and the results will be reported when available. As mentioned above, the lack of stability of cell 1 is likely due to a defective cell. This is evident from the thermal cycling data and the loss of electrolyte during cycling. Although Surlyn 1702 has a reported softening temperature of $65^{\circ} \mathrm{C}$, if the failure of cell 1 had been caused from excessive heating of the cells, both cells would have been expected to exhibit the same loss of electrolyte during rapid thermal cycling.

\section{Donor-acceptor polymers}

Donor ( $p$-type) conjugated polymers help stabilize and transport the positive charges (holes), and acceptor (n-type) conjugated polymers help stabilize and transport the negative charge (electrons). Thus photo induced electron transfer and charge separation observed in organic composites of donors and acceptors provided a potential organic molecular approach to high efficiency light harvesting or optoelectronic applications (Granstrom et al., 1998). Such systems and devices have already been demonstrated using polythiophene/CN-PPV bilayers (Granstrom et al., 1998), MEH-PPV/CN-PPV blends (Yu and Heeger, 1995), MEH-PPV/C ${ }_{60}$ bilayers and 
blends (Yu et al., 1995), MEH-PPV/PS-C 60 di-block copolymers (Stalmach et al., 2000).

In our current approach, a conjugated donor block "RO-PPV" or (D) is coupled to a conjugated acceptor block "SF-PPV" or (A) via a short non-conjugated bridge unit (B) to form a D-B-A-B type block copolymer system. In this system, the charge separation can be maximized since the interfacial area can be conveniently controlled via the size of block copolymer segment. Every donor block can be built in a convenient reach of an acceptor block, within the exciton diffusion range. On the other hand, the charge recombination between the donor and acceptor blocks at the backbone junction is hindered due to a non-conjugated aliphatic bridge unit.

Figure 4 shows the chemical structures and synthetic scheme of -DBAB-. The donor block (D) is an alkyloxy derivatized polyphenylenevinylene or "RO-PPV", and the acceptor block (A) is an alkylsulfone derivatized polyphenylenevinylene or "SFPPV". Two bridge units were investigated: the first was a dialdehyde terminated bridge (unit 1), and the second was a diamine terminated bridge (unit 2). When bridge unit 1 was used, both donor and acceptor blocks were synthesized with terminal phosphate groups. When amine terminated bridge unit 2 was used, both donor and acceptor blocks were synthesized with terminal aldehyde groups. Due to space limitations, we briefly present only the photoluminescence (PL) properties of -DBAB- in comparison to $\mathrm{D}$ and $\mathrm{A}$ blocks.

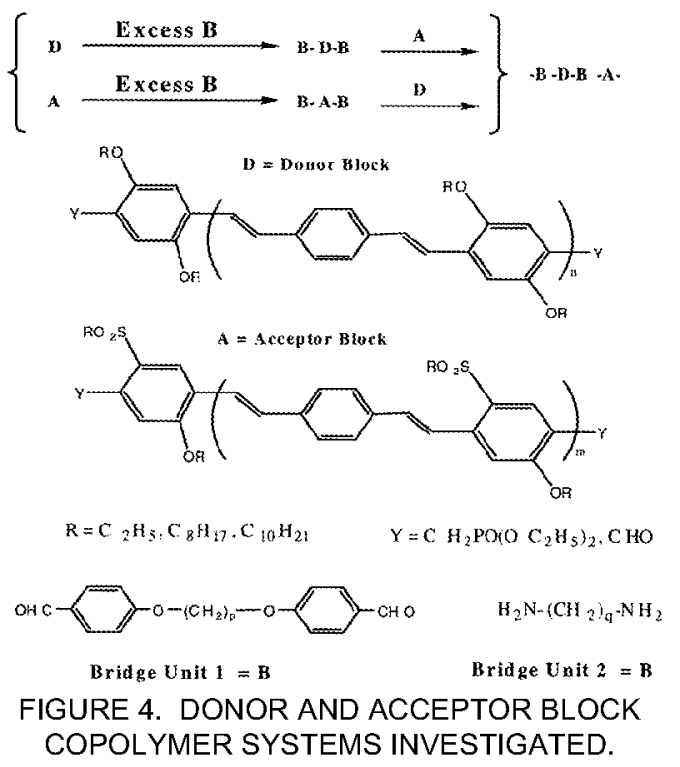

The donor block film has a PL emission maximum at $\sim 570 \mathrm{~nm}$, and the acceptor block film has a $\mathrm{PL}$ emission maximum at $\sim 590 \mathrm{~nm}$ (figure 5), yet the $\mathrm{PL}$ emission of -DBAB- film was quenched over $99 \%$. Spikes at $470 \mathrm{~nm}$ and $510 \mathrm{~nm}$ are from film reflected excitation beam. In the figure, the -BDBA-curve is arbitrarily magnified for clarity. In dichloromethane,
-DBAB- PL quenched about $80 \%$ in comparison to $\mathrm{D}$ or A. Additionally, the UV-Vis absorption spectrum of $-D B A B-$ is almost an exact overlap of $D$ and $A$. Thus ground states electron transfer in -DBAB- is not obvious, and the PL quenching is mainly due to photo induced electron transfer between donor and acceptor blocks. Preliminary AFM studies revealed certain micro phase separated pattern in the -BDBA- films on silicon substrates. Detailed microscopic studies are still underway and will be reported elsewhere.

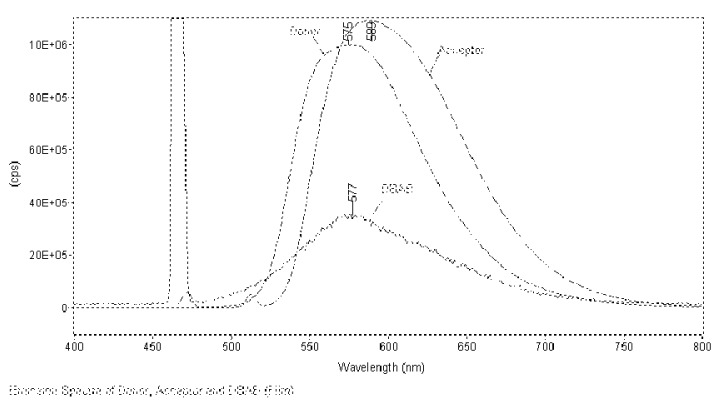

FIGURE 5. PL EMISSION SPECTRA OF D (ROPPV), A (SF-PPV), AND DBAB FILMS.

\section{Fullerene-containing Polymeric Devices}

Photovoltaic devices have been fabricated by blending $\mathrm{C}_{60}$ with conducting polymers, but the solubility of $\mathrm{C}_{60}$ is too low to achieve a high loading that can form a low resistance electron transport network. These devices have a power conversion efficiency of $\sim 3 \%$ under monochromatic light. Although this efficiency is much lower than that of silicon photovoltaic devices, the $V_{O C}$ that can be obtained is much higher ( $<1 \mathrm{~V}$ for silicon, $>2 \mathrm{~V}$ for polymer) so fewer polymer-based cells need to be put in series to achieve the same net voltage output.

To increase the efficiency of these polymer photovoltaic devices, researchers (Yu, 1995; Yu et al., 1995) developed new conducting polymer composites that contained an electron-donating species and an electron accepting species in a bicontinuous network. These photovoltaic systems are based on the mechanism of photoinduced charge separation, as previously mentioned. The most successful of these systems is based on the polymer poly $(p-$ phenylenevinlyene) (PPV). The electron donor phase utilizes a well-known soluble PPV derivative, poly (2methoxy-5-(2'-ethylhexyloxy-1,4-phenylvinylene), which is more commonly known as MEH-PPV. The acceptor phase utilizes one of two soluble forms of $\mathrm{C}_{60}$ known as $[6,6]$ PCBM and $[5,6]$ PCBM. The structures of these compounds are shown in Figure 6. Efficient current collection in these devices is achieved by using two electrode materials whose work functions span the energy of the lowest unoccupied molecular orbital (LUMO) of $\mathrm{C}_{60}$, as shown in Figure 7. The use of $\mathrm{Ca}$ (or $\mathrm{Al}$ ) as the cathode and indium tin oxide (ITO) as the anode sets up an internal field in the device in which hole are driven to the ITO:MEH-PPV: $\mathrm{C}_{60}$ interface and 


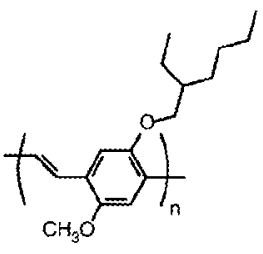

MEH-PPV

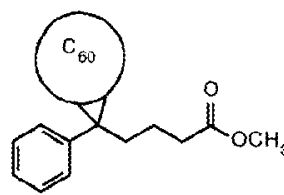

PCBM
FIGURE 6. STRUCTURES OF MEH-PPV \& PCBM.

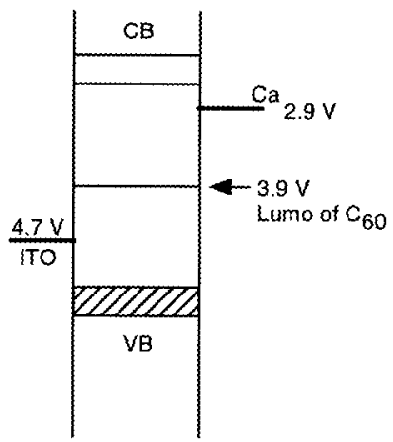

FIGURE 7. FLAT BAND SCHEME OF A CA/POLYMER + C60 $_{60} / T O$ TUNNEL DIODE. ADAPTED FROM [SARICIFTCI, 2000].

electrons are collected at the Ca:MEH-PPV: $\mathrm{C}_{60}$ interface.

The limiting factors in the performance of these devices are: 1) the number of available acceptor sites limited by the solubility of $\mathrm{C}_{60}$ in MEH-PPV, 2) the rate of electron transfer from the polymer to the electron acceptor, and 3) the limitation on electron transport in the $\mathrm{C}_{60}$ component of the bicontinuous network.

Polymers solutions were prepared by dissolving either MEH-PPV or a MEH-PPV:PCBM mixture (1:4 ratio) in chlorobenzene or chloroform, with the solid content ranging from 1 to $4 \%$. The polymer solutions were spin-coated onto ITO-coated glass fitted with wire electrodes. The resulting films ranged in thickness from 600 to $800 \AA$ for MEH-PPV:PCBM mixtures to $\sim 1000 \AA$ for MEH-PPV. Devices were fabricated by thermally evaporating a metal contact on top of the polymer film, encapsulating in glass and sealing with Master Bond EP65HT-1 epoxy to protect the device from air during evaluation (figure 8). Two contact configurations were used. The first was ITO/polymer/Ca/Al, with the metal layers each $1000 \AA$ thick. The second configuration was ITO/ polymer/LiF/Al, with a $<9 \AA$ layer of LiF instead of $1000 \AA$ of $\mathrm{Ca}$. As evident in figure 8, three devices are produce on each piece of ITO-coated glass.

To reduce premature degradation, the devices were kept in the dark until they were characterized. Devices containing PCBM showed efficiencies that were much higher than for devices with MEH-PPV alone, and device

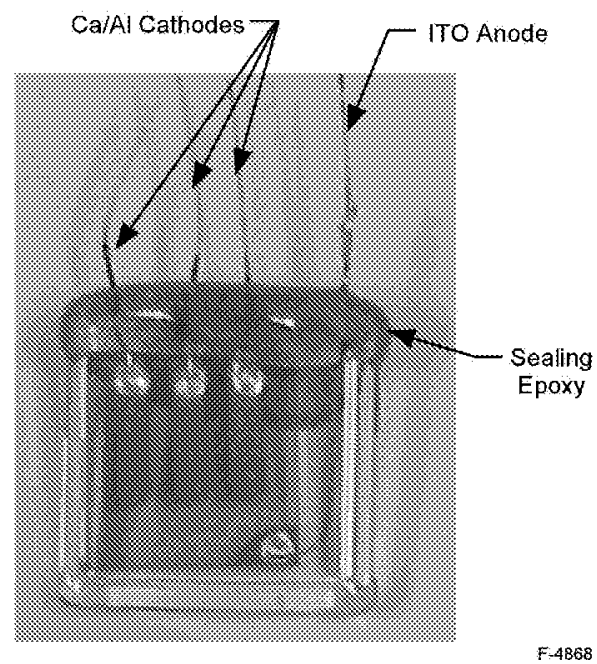

FIGURE 8. PHOTOVOLTAIC DEVICE WITH A CONFIGURATION OF ITO/MEH-PPV/CA/AL AND AN ACTIVE AREA OF $\sim 6 \mathrm{MM}^{2}$

prepared using chlorobenzene solutions showed slightly higher efficiencies than those made with chloroform. In addition, films deposited from solution containing $2 \%$ solids gave the highest efficiencies.

However, the efficiencies were much lower than those reported in the literature for similar devices. Our best device, fabricated from a $2 \%$ solids content solution in chlorobenzene, showed an efficiency of $0.14 \%$, significantly lower than the $2.5 \%$ previously reported (table 2). The open circuit potentials were approximately half of the literature values of $\sim 1.6 \mathrm{~V}$ for MEH-PPV or MDMO-PPV devices and $\sim 0.8 \mathrm{~V}$ for the PCBM-containing devices. In addition, our shortcircuit currents were significantly lower. The source of our lower efficiencies is unclear, but we suspect that purity plays a large role. Although device fabrication was performed under dust and oxygenfree conditions, extreme lengths were not taken to purify the MEH-PPV or PCBM used in the devices.

Further more, a phenomenon that has been under reported is the low stability of these devices. Neugebauer, et al. (2000) tested the stability MDMOPPV:PCBM (1:3 by mass) devices under argon for 12 hours with constant cycling from bias voltages of $-2 \mathrm{~V}$ to $+2 \mathrm{~V}$ under $10 \mathrm{~mW} / \mathrm{cm}^{2}$ of white light and observed no significant degradation. Under an atmosphere of pure oxygen, the same devices showed a factor of three decrease in the short circuit current and no decrease in the open circuit potential. However, our devices were much less stable. Figure 9 illustrates this situation, showing two cycles that were measured taken one after the other. Clearly, lifetimes for these devices are currently too short for practical applications, and this is a key area that must be address in the future. 
TABLE 2. COMPARISON OF PSI PHOTOVOLTAIC DEVICES WITH THOSE PREVIOUSLY REPORTED.

\begin{tabular}{|c|c|c|c|c|c|}
\hline Ref. & system & eff. & $\begin{array}{c}\mathrm{I}_{\mathrm{sc}} \\
\left(\mathrm{mA} / \mathrm{cm}^{2}\right)\end{array}$ & $\mathrm{V}_{\mathrm{oc}}(\mathrm{V})$ & FF \\
\hline \begin{tabular}{|c|} 
Shaheen, \\
2001
\end{tabular} & $\begin{array}{l}\text { MDMO-PPV:PCBM } \\
\mathrm{C}_{60} \text { blend (1:4 weight } \\
\text { ratio), spin coat from } \\
\text { chlorobenzene. } \\
\text { PEDOT/PSS HTL } \\
\text { and LiF/Al electrode }\end{array}$ & $2.5 \%$ & 5.25 & 0.82 & 0.61 \\
\hline $\begin{array}{c}\text { Gebeyehu } \\
2001\end{array}$ & $\begin{array}{l}\text { MDMO-PPV:PCBM } \\
\mathrm{C}_{60} \text { blend (1:3 weight } \\
\text { ratio), spin coat from } \\
\text { xylene. PEDOT hole } \\
\text { transport layer used. }\end{array}$ & $1.5 \%$ & 1 & 0.60 & 0.30 \\
\hline \begin{tabular}{|c|} 
Fromherz, \\
2000
\end{tabular} & $\begin{array}{l}\text { MDMO-PPV:PCBM } \\
\text { blend, (1:3 weight } \\
\text { ratio) }\end{array}$ & $1.5 \%$ & 0.07 & 0.72 & $\sim 0.30$ \\
\hline \begin{tabular}{|l|} 
Yu, Gao, \\
et al, 1995
\end{tabular} & $\begin{array}{l}\text { MEH-PPV:PCBM } \\
\text { blend (1:4 weight } \\
\text { ratio) spin coat from } \\
\text { dichlorobenzene }\end{array}$ & $2.9 \%$ & 2 & \begin{tabular}{|c|}
0.82 \\
(est.)
\end{tabular} & $\begin{array}{l}0.36 \\
\text { (est.) }\end{array}$ \\
\hline $\begin{array}{l}\text { same as } \\
\text { above }\end{array}$ & $\begin{array}{l}\text { MEH-PPV spin coat } \\
\text { from xylene solution }\end{array}$ & $0.02 \%$ & 0.006 & $\begin{array}{l}1.60 \\
\text { (est.) }\end{array}$ & $\mathrm{N} / \mathrm{A}$ \\
\hline $\begin{array}{l}\text { Marcos } \\
\text { Ramos, } \\
2001\end{array}$ & $\begin{array}{l}\text { Poly(phenylene } \\
\text { ethynylene vinylene) } \\
\text { with pendant } \mathrm{C}_{60} \text {, } \\
\text { spin coat from } \mathrm{CHCl}_{3} \text {. } \\
1 \mathrm{C}_{60} \text { every } 4 \text { units. }\end{array}$ & $0.10 \%$ & 0.42 & 0.83 & 0.29 \\
\hline PSI & $\begin{array}{l}\text { MEH-PPV:PCBM } \\
\text { blend (1:4 weight } \\
\text { ratio) spin coat from } \\
\text { a } 2 \% \text { chlorobenzene } \\
\text { sol'n }\end{array}$ & $0.14 \%$ & 0.027 & 0.45 & 0.45 \\
\hline PSI & $\begin{array}{l}\text { MEH-PPV:PCBM } \\
\text { blend (1:4 weight } \\
\text { ratio) spin coat from } \\
\text { a } 2 \% \text { chlorobenzene } \\
\text { sol'n }\end{array}$ & $0.11 \%$ & 0.255 & 0.38 & 0.29 \\
\hline PSI & $\begin{array}{l}\text { MEH-PPV spin coat } \\
\text { from a } 2 \% \text { xylene } \\
\text { solution }\end{array}$ & $\begin{array}{l}4.57 x \\
10^{-5} \%\end{array}$ & $9.61 \mathrm{E}-5$ & 0.80 & 0.15 \\
\hline
\end{tabular}

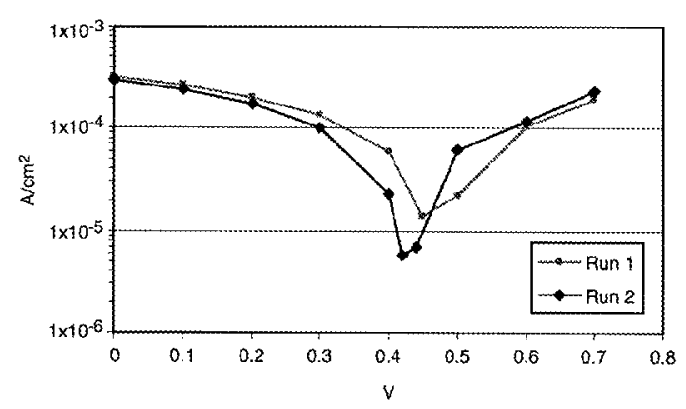

FIGURE 9. TWO SUBSEQUENT SCANS OF A PSI DEVICES FABRICATED FROM A $2 \%$ CHLOROBENZENE SOLUTION.

\section{REFERENCES}

Amirnasr, M., Nazeeruddin, M.K., and Grätzel, M., 2000 , "Thermal stability of cis-dithiocyanato(2,2'bypyridyl-4,4'-dicarboxylate) ruthenium(II) photosensitizer in the free form and on nanocrystalline $\mathrm{TiO}_{2}$ films," Thermochimica Acta, 348, 105-114.
Bach, U., Lupo, D., Comte, P., Moser, J.E., Weissörtel, F., Salbeck, J., Spreitzer, H., and Grätzel, M., 1998 "Solid-state dye-sensitized mesoporous $\mathrm{TiO}_{2}$ solar cells with high photon-to-electron conversion efficiencies," Nature, 395, pp. 583-585.

Bailey, S.G. and Flood, D.J., 1998, "Space Photovoltaics," Prog. Photovolt: Res. Appl., 6, pp. 1-14.

Fromherz, T., Padinger, F., Gebeyehu, D., Brabec, C., Hummelen, J.C., and Sariciftci, N.S., 2000, "Comparison of photovoltaic devices containing various blends of polymer and fullerene derivatives," Solar Energy Materials and Solar Cells, 63, pp. 61-68.

Granstöm, M., Petritsch, K., Arias, A.C., Lux, A., Andersson, M.R., and Friend, R.H. 1998, "Laminated fabrication of polymeric photovoltaic diodes," Nature, 395, pp. 257-260.

Grätzel, M., 2000, "Perspectives for Dyesensitized Nanocrystalline Solar Cells," Prog. Photovolt. Res. Appl., 8, pp. 171-185.

Green, M.A., Emery, K., King, D.L., Igari, S., and Warta, W., 2001, "Solar Cell Efficiency Tables (Version 18)," Prog. Photovolt: Res. Appl., 9, pp. 287-293.

Hinsch, A., Kroon, J.M., Kern, R., Uhlendorf, I., Holzbock, J., Meyer, A., and Ferber, J., 2001 "Longterm Stability of Dye-Sensitized Solar Cells," Prog. Photovolt: Res. Appl., 9, pp. 425-438.

Kohle, O., Grätzel, M., Meyer, A.F., and Meyer, T.B., 1997, "The Photovoltaic Stability of Bis(isothiocyanato)ruthenium(II)-Bis-2,2'-bypyridine-

4.4'-dicarboxylic Acid and Related Sensitizers," Adv. Mater, 9, 904-906.

Nazeeruddin, M.K., Kay, A., Rodicio, I., HumphryBaker, R., Müller, E., Liska, P., Vlachopoulos, N. and Grätzel, M., 1993, "Conversion of Light to Electricity b y $\quad$ c i s $-X_{2} \operatorname{Bis}(2,2$ '-bipyridyl-4,4'-dicarcoxylate) ruthenium(II) Charge-transfer Sensitizers $(X=\mathrm{Cl}$-, Br-, $\mathrm{I}-, \mathrm{CN}-$, and SCN-) on Nanocrystalline $\mathrm{TiO}_{2}$ Electrodes, J. Am. Chem. Soc., 115, pp. 6382-6390.

Neugebauer, H.; Brabec, C.; Hummelen, J.C.; Sariciftci, N.S, 2000, "Stability and photodegradation mechanisms of conjugated polymer/fullerene plastic solar cells," Solar Energy Materials and Solar Cells, 61 , pp. 35-42.

Shaheen, S.E., Brabec, C.J., Sariciftci, N.S., 2001, "2.5\% efficient organic plastic solar cell," Applied Physics Letters, 78, pp. 841-843.

Stalmach, U., Boer, B.D., Videlot, C., van Hutten, P.F., and Hadziioannou, G., 2000, "Semiconducting Diblock Copolymers Synthesized by Means of Controlled Radical Polymerization Techniques," J. Am. Chem. Soc., 122, pp. 5464-5472.

Yu, G., Gao, J., Hummelen, J.C., Wudl, F., Heeger, A.J., 1995, "Polymer Photovoltaic Cells: Enhanced Efficiencies via a Network of Internal Donor-Acceptor Heterojunctions," Science, 270, pp. 1789-1791.

Yu, G. and Heeger, A.J., 1995, "Charge separation and photovoltaic conversion in polymer composites with internal donor/acceptor heterojunctions," Journal of Applied Physics, 78, pp. $4510-4515$. 
\begin{tabular}{l|l|l|l|l|}
\hline 1. AGENCY USE ONLY (Leave blank) & 2. REPORT DATE & 3. REPORT TYPE AND DATES COVERED
\end{tabular}

\begin{tabular}{|c|c|c|} 
AugUSt 2002 & Technical Memorandum
\end{tabular}

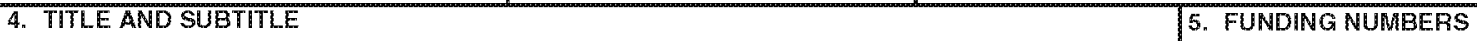

Thin-Film Organic-Based Solar Cells for Space Power

6. ABTHOR(S)

WU-755-A4-01-00

Sheila G. Bailey, Ierry D. Harris, Aloysius F. Hepp, Emily I. Anglin,

Ryne P. Raffaelle, Harry R. Clark, Ir., Susan T.P. Gardner, and Sam S. Sun

7. PERFORMING ORGANIZATION NAME(S) AND ADDRESS(ES)

National Aeronautics and Space Administration

John H. Glenn Research Center at Lewis Field

Cleveland, Ohio 44135-3191

9. SPONSORING/MONITORING AGENCY NAME(S) AND ADORESS(ES)

10. SPONSORING/MONITORING AGENCY REPORT NUMBER

National Aeronautics and Space Administration

Washington, DC 20546-0001

NASA TM-2002-211833

IECEC-2002--20154

\section{SUPPLEMENTARY NOTES}

Prepared for the $37 \mathrm{th}$ Intersociety Energy Conversion Engineering Conference sponsored by the Institute of Electrical and Electronics Engineers, Electron Devices Society, Washington, DC, July 28-August 2, 2002. Sheila G. Bailey and Aloysius F. Hepp, NASA Glenn Research Center; Jerry D. Harris, Cleveland State University, Cleveland, Ohio; Emily J. Anglin, Ohio Aerospace Institute, Brook Park, Ohio; Ryne P. Raffaelle, Rochester Institute of Technology, Rochester, New York; Harry R. Clark, Jr., Townsend Science and Engineering, Inc., Fitchburg, Massachusetts; Susan T.P. Gardner, Physical Sciences, Inc., Andover, Massachusetts; and Sam S. Sun, Norfolk State University, Norfolk, Virginia. Responsible person, Sheila G. Bailey, organization code 5410, 216-433-2228.

$\begin{array}{ll}\text { 12a. DISTRIBUTION/AVAILABILITY STATEMENT } & \text { 12b. DISTRIBUTION CODE }\end{array}$

Unclassified-Unlimited

Subject Category: 25

Distribution: Nonstandard

Available electronically at mo//ghrs.grcinasizow

This publication is available from the NASA Center for AeroSpace Information, 301-621-0390.

13. ABSTRACT (Maximum 200 words)

Recent advances in dye-sensitized and organic polymer solar cells have lead NASA to investigate the potential of these devices for space power generation. Dye-sensitized solar cells were exposed to simulated low-earth orbit conditions and their performance evaluated. All cells were characterized under simulated air mass zero (AMO) illumination. Complete cells were exposed to pressures less than $1 \times 10^{-7}$ tor for over a month, with no sign of sealant failure or electrolyte leakage. Cells from Solaronix SA were rapid thermal cycled under simulated low-earth orbit conditions. The cells were cycled 100 times from $-80^{\circ} \mathrm{C}$ to $80^{\circ} \mathrm{C}$, which is equivalent to 6 days in orbit. The best cell had a 4.6 percent loss in efficiency as a result of the thermal cycling. In a separate project, novel -Bridge-Donor-BridgeAcceptor- (-BDBA-) type conjugated block copolymer systems have been synthesized and characterized by photoluminescence (PL). In comparison to pristine donor or acceptor, the PL emissions of final $-B-D-B-A-b l o c k$ copolymer films were quenched over 99 percent. Effective and efficient photo induced electron transfer and charge separation occurs due to the interfaces of micro phase separated donor and acceptor blocks. The system is very promising for a variety high efficiency light harvesting applications. Under an SBIR contract, fullerene-doped polymer-based photovoltaic devices were fabricated and characterized. The best devices showed overall power efficiencies of $\sim 0.14$ percent under white light. Devices fabricated from 2 percent solids content solutions in chlorobenzene gave the best results. Presently, device lifetimes are too short to be practical for space applications.

\section{SUBJECT TERMS}

Photovoltaic; Space power

17. SECURITY CLASSIFICATION OF REPORT

Unclassified
18. SECURITY CLASSIFICATION OF THIS PAGE

Unclassified
19. SECURITY CLASSIFICATION OF ABSTRACT

Unclassified

NSN 7540-01-280-5500

15. NUMBER OF PAGES

12

16. PRICE CODE

\section{LIMITATION OF ABSTRACT}

